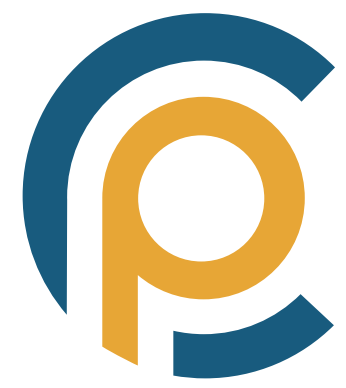

\title{
Sho'ah: Plasticidad del Horror. Estética, Realidad y Compromiso en la Historia del Arte
}

\author{
Sho'ah: Plasticity of Horror. \\ Aesthetics, Reality and Commitment \\ in Art History
}

Recibido: 01/04/2020 | Revisado: 19/05/2020 | Aceptado: 01/06/2020 | Publicado: 30/06/2020

Resumen: La producción artística o literaria posterior al holocausto posee un innegable valor documental, pero no contribuye tanto al esclarecimiento de lo ocurrido como a la expresión de lo que realmente sentimos y la actitud que hemos decidido adoptar para relacionarnos con ese pasado que ha acabado por convertirse casi en un objeto físico. El objetivo principal de este trabajo es sin duda advertir del peligro de acabar considerando algo meramente estético lo que ante todo debe ser un documento y un monumento perenne al recuerdo y la memoria. Así mismo pretendemos concienciar a los historiadores de arte en su doble faceta, también como historiadores, que esta tarea de advertencia en general les corresponde por su vínculo a los sistemas de divulgación del conocimiento de estas piezas tan sensibles. Para ello hemos utilizado una metodología esencialmente formalista, habitual en la historia del arte, analizando textos y testimonios como medida correctora que dé sentido al significado de las piezas, pero basándonos esencialmente en la propia imagen y su valor como significante. A partir de ahí se pretende construir todo un edificio explicativo y de compromiso profesional.

Palabras clave: documentación, educación estética, educación artística, educación para la paz, fotografía, guerra, holocausto, valores.
Abstract: Post-holocaust artistic or literary production has undeniable documentary value. However, it does not contribute so much to clarify what happened but to express what we are feeling now. This production explains better the attitude we have decided to adopt to relate to that past. The main objective of this work is undoubtedly to warn of the danger of ending up considering something as merely aesthetic what must first and foremost be a document and a perennial monument to remembrance and memory. Likewise, we intend to make art historians aware that this task of warning corresponds to them since they have a stark link to the systems of knowledge about these pieces. So we have used an essentially formalist methodology that is common in art history. We have analyzed texts and testimonies as a corrective measure that gives meaning to the pieces. And then we have studied the image itself and its value as a signifier. We intended to build a professional commitment structure for art historians.

Keywords: aesthetic education, art education, documentation, holocaust, peace education, photography, values, war. 
Lo horrible es innato en el hombre -no sólo en una sociedad que fuera aberrante- y he sentido el deber de decirlo así. Zoran Mušič

Escoge lado. La neutralidad ayuda al opresor, nunca a la víctima. Elie Wiesel

La configuración de la mirada del espectador: la distancia del objeto

La obra de arte no es más que una representación. Es la materialización de un concepto al que ella misma nos remite y un vehículo de contacto entre sujeto e idea. Esta que es su naturaleza es también aquello que la completa y hace perfecta. La distancia entre el objeto y el sujeto no depende solo de la ubicación real de ese concepto, sino sobre todo del esfuerzo e interés que el sujeto demuestre para alcanzarlo. Todo aspecto material en la obra actúa siempre como reclamo para atrapar el concepto. Cuando esto sucede, el objeto puede ya pasar inadvertido para siempre y convertirse en mera pieza decorativa. Pero puede también suscitar una comprensión nueva de la idea cada vez. No obstante, siempre será el sujeto quien decida el modo e intensidad y optará así por una solución diferente dependiendo de la ocasión. Su decisión puede diferir respecto a la de otro sujeto, otro momento o incluso respecto a la tomada por él mismo en cualquier otra ocasión. En cualquier caso, la respuesta del espectador dependerá de cómo identifica la obra en ese instante. El momento, el lugar y el público hacen del encuentro algo excepcional (Sontag, 2004, p. 25). El vínculo entre sujeto, objeto y concepto es por tanto único en cada ocasión. Es por esto que esa relación solo es perfecta cuando el sujeto adquiere en ella la capacidad de explicarla e interpretarla, descubriendo cuál es la representación que la anima. Sin embargo, una inmensa mayoría de los objetos materiales referidos al holocausto no nació con esa necesidad de remitir a una representación y adquiere esa virtud a posteriori y forzadamente. Nuestra cultura nos ha acostumbrado a pensar que los objetos de un museo tienen un valor artístico o equivalente y esto no siempre es cierto. De ahí que se generen enormes problemas de medición de distancias entre espectador y objetos del horror, pues hacemos que la artisticidad actúe como patrón de medida y esta, en ocasiones, por más que la busquemos se encuentra ausente. Lo artístico es de naturaleza expresiva y está reñido con lo inefable, con la imposibilidad del horror de enunciarse a sí mismo. Por eso es necesario reconocerla en cierto grado en estos objetos y conferirles así la oportunidad de decir lo que ellos mismos representan, si no con palabras, sí al menos con imágenes. El horror adquiere notas insospechadas en los conflictos bélicos contemporáneos. La guerra no es ya solo una máquina de matar, sino una industria de la muerte. No solo se convierte en la escala, sino también en un sinsentido que repugna al mismo ser humano que la mantiene en funcionamiento. Repugna la barbarie y repugna el hecho de que niega lo más básico de la especie humana, la individualidad. La guerra cosifica y masifica a las víctimas negándoles cualquier intento de subjetivización y, por ende, de expresión. Las víctimas son números informes que ni hablan por sí mismos ni expresan otra cosa que a sí mismos como total. La condición de víctima está reñida con la artisticidad, pues todo lo que la atañe es ajeno al arte. Muchos de los reporteros que fotografiaron la guerra o sus ocultos horrores en los campos de muerte eran judíos. Jamás sabremos hasta qué punto pudo afectar este hecho el modo de visión de los objetivos de sus cámaras, pero no cabe duda de que algunos estaban personalmente implicados en el conflicto (Shneer, 2010, p. 31). Esto significaba que, interna o exteriormente, se les suponía y exigía un compromiso mayor por el simple hecho de ser también víctimas colaterales.

\section{Holocausto: visión y símbolos}

Pese a su innegable valor documental, la producción artística o literaria posterior al holocausto no contribuye tanto al esclarecimiento de lo realmente ocurrido como a la expresión de la realidad de lo que sentimos. Parece explicar mucho mejor el modo que hemos decidido adoptar para relacionarnos con ese pasado que ha acabado por convertirse casi en un objeto físico. La proyección sentimental de este objeto y su representación material se asienta en el reflejo de unos valores y conceptos muy precisos que han hecho de este arte del holocausto o post-holocausto (Lang, 2005) también un arte simbólico. Lo material es un mero referente a un conjunto de connotaciones éticas suscitadas por una historia real que 
obliga a replantearse conceptos y a definir personas y personajes: el mal, la víctima, el perdón... Pero el historiador del arte, con frecuencia, no se preocupa de dar una interpretación filosófica a ese mundo ético al que la obra nos remite. Lo habitual es que tan solo pretenda constatar la posibilidad de interpretación de un modo científico. Esta postura fría y distante adoptada en la correspondencia con su objeto de estudio le permite mirarlo frente a frente y establecer un sistema de relaciones significativas sin ceder al peso excesivamente sensible de su contenido.

La historia del arte considera que el arte consiste esencialmente en la creación de imágenes. Son imágenes vinculadas al momento que prefiguran y dotadas, por tanto, de un sentido histórico. De alguna manera la imagen es solo un sustituto equivalente de lo real, nunca lo real en sí. Jamás podrá sustituirlo por completo ni actuar como tal. La imagen, cualquier imagen, compromete así seriamente la realidad y su alianza con la veracidad y la historia. En otras palabras: ¿es real aquello a lo que me remite la imagen o no? ¿es válida la simbolización de la realidad o nos moveremos eternamente en la incertidumbre? ¿puede la imagen darnos certeza de un momento concreto? Lejos de ahondar en el planteamiento filosófico de la verdad y su temporalización, la cuestión resulta esencial cuando intentamos aclarar el valor simbólico de la imagen referida al holocausto. La imagen del holocausto le concede un lugar en la historia (Wajcman, 2003, p. 62), también en la historia de la sentimentalidad humana. El historiador del arte no puede olvidar en su interpretación que el holocausto ha pasado a convertirse en una clara seña de identidad judía. Al margen de su procedencia geográfica, cualquier comunidad judía identifica como propio lo sucedido en Europa. En el caso de Estados Unidos llega incluso, como señala Novick (1999, p. 7), a satisfacer la necesidad de un símbolo consensuado que procurase un motivo al conjunto para mantener su diferencia ante el peligro de disolución y asimilación plena en el entorno. La identificación de holocausto con identidad judía debe figurar en la base de cualquier lectura de este arte, aunque sea a costa de trasladar el problema de la tragedia del horror al ámbito nacional, social o político. Es así una trasgresión de lo real en la medida en que se produce una apropiación del tema por solo una de las partes, el judaísmo. No obstante, el holocausto, no debemos olvidarlo, no es solo una cuestión judía. Es esto lo que facilita su comprensión al margen del judaísmo, pero es lógico que se produzca esta focalización sobre la víctima hasta el punto de presentarla como la única posible: nada es comparable al holocausto judío. Fue un episodio único en la historia de la humanidad y, por tanto, crucial para la historia del judaísmo como principal afectado, pero también para la historia de la especie.

El uso indebido de la imaginería y el vocabulario propios del holocausto puede contribuir a trivializar el hecho e incluso a una desvirtualización total de la realidad cuando ambos son utilizados para sostener causas que, como las faltas y crímenes derivados de los procesos de colonización, nada tienen que ver con lo ocurrido con el pueblo judío en la Europa del siglo XX (MacDonald, 2007, p. 996). La construcción de una imagen banal del holocausto, presentándolo como uno más de los muchos episodios de odio a lo largo de la historia de la humanidad, es peligrosa por varios motivos. Un ejemplo lo tenemos en el torticero procedimiento de apelar a una sentimentalidad ya consolidada (MacDonald, 2007, p. 1009), como la simpatía por las víctimas judías, para focalizar la atención sobre procesos muy distintos, como el acoso a las comunidades indígenas, por ejemplo. Tales patrones no son aplicables a estos casos. La banalización es también peligrosa porque nos aleja del conocimiento real de lo sucedido y nos induce a pensar que el holocausto judío podría ser estudiado desde un contexto muy diferente del que lo generó. El problema que plantea la imagen del holocausto es una cuestión de límites de significado. La representación del horror en sí misma no tiene más sentido que el documental, pero la mirada del fotógrafo o del artista plástico y literario le confiere un nuevo valor simbólico, libre y convencional. Este valor se acentúa en el momento en que la reflexión del autor, la obra de arte, se viraliza y comienza a ser percibida en contextos variados y diferentes. La simbolización de la imagen del holocausto lleva implícita una cierta descontextualización y, por tanto, es susceptible de un cierto desvío en la comprensión de su auténtico significado. Es cierto que la imagen, particularmente la fotografía por causa de su alianza con la verdad, condiciona nuestro modo de percibir unos hechos en los cuales no nos hemos visto involucrados. Pero no lo es menos que compartir la imagen y los sentimientos provocados en cada sujeto con un grupo más amplio deterrmina también la creación de una especie de conciencia colectiva falseada. La historicidad 
se define entonces a partir de la sentimentalidad colectiva, al tiempo que se da el rango de icono simbólico a lo que no es más que un documento. Ver la realidad a través de este tipo de símbolos es asistir más que a lo real en sí a una ficción muy próxima, pero en cualquier caso artificial y convencional.

\section{Arte y shoá: la función y el sistema de valores}

Esta barbarie es un crimen sin imágenes, aunque con muchos testimonios: nada gráfico que nos remita a algo tan sórdido, pero muchas palabras que liberan la imaginación. Quizás por ello, en relación al tema, sea más abundante la obra literaria que la plástica. Quizás también por esto la plástica se impregna de abundantes contenidos literarios que intentan rellenar el hueco dejado por la imagen como referente. El exterminio pretendía borrar en silencio la memoria judía que un día existió. El hueco, la ausencia, como señala Wajcman (2005, p. 17), encuentra en el arte su mejor modo de manifestación y evidencia Para este psicoanalista, el siglo XX se caracteriza por la invención del deber de memoria. Esto conduce paradójicamente a lo contrario, al olvido, pues elevar monumentos es, después de todo, y principalmente, una manera de organizar la 'tumba del pasado' (Wajcman, 2005, p. 14). El deber de memoria ha sido asumido por el estado, especialmente en este caso. Su compromiso es expresar lo inefable y representar lo que no tiene siquiera una imagen de referencia, habida cuenta de que las víctimas, que son las únicas que podrían haber recordado algo, fueron enmudecidas. La mayor dificultad en el estudio histórico de este período de terror surge al comprender que los documentos nos obligan inexorablemente a adoptar una postura explicativa desde la víctima o desde el opresor y que eso significa de algún modo tomar partido por un modelo historiográfico determinado. La historia fue contada en sus primeros momentos desde Europa o Estados Unidos poniendo su atención en la documentación producida por el aparato germano. Solo a partir de Friedman (1976, p. 643) y sus seguidores israelíes comienza a prestarse atención al mundo global judío bajo ese gobierno nazi y a analizar pormenorizadamente cada aspecto de la vida judía, incluida la intelectualidad y el arte. La escuela israelí hace del pueblo judío un sujeto histórico, lo libera de su papel de víctima y lo convierte en un sujeto capaz de resistir frente a la maquinaria nazi (Gutman, 2002, pp. 109-125). Se evita al menos la imagen de cordero indefenso, inerme e inerte ante el horror, como crítica y duramente señalaría Slavoj Zizek al periódico Ha'aretz: "The perception of the Holocaust in terms of a tragedy does an injustice to the real extent of the horror and shrinks it to the dimensions of the normal. In this there is a kind of denial of the magnitude of the disaster." (Wolkstein y Mishani, 2006, 5 de septiembre).

\section{La artisticidad del documento gráfico: la inmediatez de la fotografía y la estética del horror}

El intento nazi de exterminio industrializado y sistemático constituye un hito para demasiadas cuestiones relacionadas con el concepto de humanidad, también para el arte. Es una subversión de cualquier valor humano, altera la evolución normal de la especie y no puede ser obviada su influencia, ya sea por acción o por omisión. Si al entender de Adorno, la poesía quedaba muda tras el horror, tal vez el momento posterior al espanto fuese la ocasión propicia para dar una oportunidad a las artes plásticas y que ayudasen así a explicar lo que no tenía explicación posible. Al fin y al cabo, son esa naturaleza expresiva y la capacidad de no requerir palabras precisas para explicar conceptos lo que hacen interesante a la práctica artística. Sin embargo, el holocausto obliga al arte a "presenciar el desmoronamiento de las formas de representación" (Godfrey, 2007, p. 13) tradicionales y a plantearse otras vías. El problema del naturalismo era su estrecha y explicita complicidad con la plasmación del horror. La sustitución de la sugerencia por la inmediatez de la imagen, puede ser demasiado hiriente para una sensibilidad aterrada ante lo inconcebible por inefable. La abstracción, sin embargo, permitía a cada espectador recibir el mensaje en el grado de crudeza soportado o deseado por él mismo. La figuración del holocausto a través del arte abstracto no solo es válida, puesto que la abstracción también explica conceptos y sitúa ideas en una línea temporal, sino que goza de la ventaja de poder graduar su intensidad y alcance. La fotografía por el contrario, inmediata y explícita, se halla fuera del ámbito de la expresión, es esencialmente precisa y comunicativa y añade los valores de certeza y credibilidad a lo representado. La imaginación parte de un hecho entendido como real e innegable y es libre de construir cuantos edificios quiera a partir de la imagen, pero ese edificio que muestra impreso sobre el papel es el único con sólidos cimientos. 
Este valor resulta ambivalente y cuestiona el papel de la fotografía como documento representativo o histórico, si no se apoya en un conocimiento sólido de lo acaecido. La relación del espectador con la imagen es siempre la de un lector de códigos. Él debe desentrañarla, pero a menudo no es más que una propuesta abierta que cierra y completa a su antojo. Ese es nuestro modo humano de percibir la realidad. Las artes plásticas conceden esa libertad del antojo y nos han habituado a ella, pero la fotografía la limita sobremanera exigiendo del espectador el conocimiento pleno de la línea temporal y de los hechos ubicados sobre ella: de no ser así, la interpretación del espectador podría convertir en documento falso lo que es un hito garante de veracidad. La fotografía documental comienza a experimentar un tímido cambio en el período de entreguerras consistente en la intensificación paulatina de sus posibilidades artísticas mediante la incorporación de nuevos recursos técnicos. Se trata de procesos que condicionan y cambian la lectura y comprensión de la imagen, que no eran gratuitos en absoluto, pues podían responder tanto a intenciones puramente estéticas como de naturaleza ideológica (Shneer, 2010, p. 44). La imagen fotográfica, antes de su decodificación, ha de ser minuciosamente procesada y catalogada y debe ser ubicada en las condiciones históricas espacio-temporales que la sostienen. La ausencia de estetización en la mirada que requiere este tipo de documento lo hace inestimable para la representación del holocausto, mucho más quizás que la obra de arte. Sin embargo, hoy cuestionamos como nunca su idoneidad. Tal vez el problema no deriva de la técnica, sino de su finalidad o de su definitiva conversión en una forma artística contemporánea más. También pudo resultar decisiva la subsecuente educación de las generaciones posteriores a la masacre dentro de una forma de lectura e interpretación de la imagen fotográfica mucho más artística que documental.

La fotografía, como representación veraz del horror, es cuestionada a causa de la contaminación o hibridación que se ha producido en la cultura contemporánea con el campo de las artes, a causa de su estetización. La estetización de la fotografía es en cierto modo inevitable, ya que "el tiempo termina por elevar casi todas las fotografías, aun las más inexpertas, a la altura del arte" (Sontag, 2008, p. 30). Pero aunque pudiese salvarse esta cuestión, seguiríamos poniendo reparos a su uso por la excesiva crudeza con que mimetiza lo real y el hecho de nacer de un acto de fuerza o violencia añadida sobre la voluntad de la víctima. De esta suerte, no queda más posibilidad que un compromiso intermedio, en que la imagen signifique lo que representa, comunicando su realidad, pero permita de idéntico modo abrir la puerta a una libre expresión de los sentimientos suscitados. En cualquier caso, como género especial, la fotografía del horror sigue siendo necesaria. Otras artes, como la pintura o la escultura, empeñadas en otras aventuras expresivas, tras la Segunda Guerra Mundial, jamás conseguirán el grado de precisión y mimetización. Simplemente queda patente su especificidad y por tanto, la necesidad de unos nuevos mecanismos y hábitos de interpretación.

\section{La documentalidad de la pieza artística nacida del holocausto: la plástica del testimonio y la memoria}

En esta especial relación con la realidad, el fotógrafo no actúa sobre el objeto representado, tan solo sobre el modo de ofrecerlo a través del manejo de la cámara. De suerte que lo artístico viene determinado más por la realidad del objeto que por el mundo interior del sujeto artista (Keilbach y Wächter, 2009, p. 55). Predomina así su carácter documental y nos obliga a la concesión del valor de única realidad posible y objetiva. Desde su invención, la historia no ha tenido mejor apoyo documental y ni siquiera un texto puede explicar tanto tan explícitamente. La escasez de manifestaciones plásticas artísticas coetáneas y paralelas a los hechos revaloriza extraordinariamente la consideración de las pocas muestras existentes, pero no nos permite articular una teoría objetiva y acertada sobre la relación del tema con el arte, de modo que acabamos inscribiéndolo en capítulos historiográficos ya asentados: la violencia en la historia del arte, el mal, el tratamiento artístico de la moral... La fotografía del holocausto suele ilustrar y acompañar discursos de carácter histórico como documento. Este uso como soporte de narración histórica genera una distorsión grave en la veracidad de la realidad que representa, pues la imagen queda como mero apéndice de un edificio expresivo articulado premeditado e intencionado, como es el texto redactado por el historiador. La distorsión es aún mayor cuando, inscrita en el cuerpo general del texto, la imagen se acompaña de un pie o título que condensa y responde a la intención 
ideológica o metodológica de quien la usa. Barnouw (1996) analizó los contenidos de estos títulos, a menudo inculpatorios, pues buscaban responsabilizar a una población alemana que con la derrota había heredado la culpa, incluso de todo cuanto desconocía. La ignorancia fue la autoexculpación alegada por el pueblo alemán, que no salía de su estupor ante lo que las imágenes revelaban. La fotografía no es una ilustración para los libros de historia, ya que los contextos personales y circunstanciales cambian y afectan enormemente a su lectura.

Como documento, tampoco la imagen puede resolver por sí sola la enorme complejidad de los hechos. La fotografía carecía de interés para el campo de la historia, precisamente por su escaso aporte frente a otro tipo de objetos. Las imágenes de los campos fueron tomadas como prueba y testimonio ante la duda previsible y la incredulidad de la masa ajena a todo lo sucedido. Ofrece aspectos de lo real, pero no lo agota y aunque actualiza lo ocurrido y lo re-presenta rescatándolo del olvido del pasado, es sólo un simple apoyo que requiere ser acompañado de otros muchos más de naturaleza variada, fundamentalmente textos. Una buena parte del material disponible responde al enfoque de un fotógrafo totalmente ajeno a la situación y que llega a conocer el horror acompañando a las tropas victoriosas. Este tiende a leer lo que capta su objetivo como una simple consecuencia del proceso bélico y no como el auténtico crimen contra la humanidad que realmente fue y cuya auténtica naturaleza se desvela solo tras el conflicto. El reportero realiza la lectura de lo que capta desde sus propios esquemas histórico-artísticos y sus principios éticos, enlazando lo que ve a su moral judeocristiana occidental, reconvirtiendo escenas y plasmando personajes del mismo modo que el barroco católico había llenado sus iglesias con arquetipos personificados en mártires, santos e imágenes sagradas. La fotografía periodística del horror tiene así algo de barroco, en cierto modo ambas manifestaciones tienen como base la tragedia y la pasión del ser humano. Esta hibridación no deja de ser también una falsificación: la instantánea se vacía de su contenido real y se lo sustituye por un referente histórico y artístico, esencialmente religioso, fácilmente comprensible para la cultura occidental. Es la acomodación a un símbolo ya constituido, de una realidad puntual, el holocausto, pero entendida como realidad humana eterna, repetible a lo largo de la historia de la humanidad. Este tipo de reinterpretación erradica la especificidad del exterminio judío.

El sesgo y en cierto modo la distancia entre el fotógrafo y la realidad de su obra son dos notas más de distorsión en la validez documental de estas imágenes. Quienes realizaron este tipo de fotografías declararon haberlo hecho como la única manera posible de demostrar al mundo y a sí mismos, incrédulos todos pese a la evidencia, la veracidad del horror con que se toparon. Es una fotografía aséptica de carácter claramente documental, que constata el hecho, pero desconoce su verdadero alcance y objetivo. Fue el instrumento de los vencedores para mostrar la carencia total de valores de los vencidos y el grado de inhumanidad al que conduce la vida al margen de las excelencias de la democracia occidental. Son muy escasas las imágenes tomadas por las propias víctimas. De existir un mayor número, seguramente se habrían centrado en documentar y denunciar el crimen, pero no fue así y todo sucedió en silencio, sin más pruebas que los restos e instantáneas aparecidos tras el final de la guerra. Esta carencia documental sustenta una cierta falta de credibilidad en relación a los hechos narrados a posteriori. El tema planteado es el de la posibilidad de representar verazmente los acontecimientos o no (Wajcman, 2001, p. 48) ante la falta de documentos gráficos sobre el crimen en sí. Los historiadores suplieron esta ausencia incorporando a su discurso las declaraciones de las víctimas. Como parte del texto, daban mayor autenticidad a sus argumentos explicativos sobre el porqué y el cómo de la barbarie (Goldberg, 2009, p. 222). La imagen no permite este recurso, a lo sumo lo suple mediante el título a pie de foto, pero ante la escasez de testimonios escritos en aquel momento sobre la vida en los campos, adquiere un valor documental esencial.

Las cuatro imágenes tomadas en agosto de 1944 por los miembros de un Sonderkommando en Auschwitz, serían tal vez las únicas nacidas con un claro cometido sólo documental. Aunque no digan toda la verdad, estas son la única verdad que queda. El valor concedido a estas fotos-desgarro (photo-déchirure) por Georges Didi-Huberman (2001, pp. 219-242), que acuñó esta expresión para 
ellas, suscitó una enorme polémica en torno a la relación entre imagen fotográfica, realidad y verdad. Didi-Huberman hace de estas fotos las mejores pruebas testimoniales y la evidencia de una voluntad de resistencia y supervivencia del recuerdo nítido. Él pretende que las fotos de Auschwitz sean tomadas como prueba material y testigos silenciosos por su singularidad (Feyertag, 2008), de una manera estricta y objetiva que nada deja a la imaginación. Pero niega la irrepresentabilidad del delito tradicionalmente admitida y afirma que es el sujeto quién construye la imagen (Wajcman, 2001, p. 49) y que, por esta causa, basta con cambiar el punto de vista para apreciar en las muestras ofrecidas las cámaras de gas. La objetiva inconsistencia de unas imágenes relativas, por cuanto requieren de un cambio en el espectador, suscitó una enorme polémica académica sobre el valor de estas pruebas. Se opone así a la idea de Claude Lanzman (1994), quien concede al testimonio oral de las víctimas y su capacidad de sugerencia el mayor peso a la hora de reconstruir la verdad de lo sucedido, sobre todo habida cuenta de que se intentó silenciar a toda costa lo acaecido entre sus vallas y solo las declaraciones de estas personas vinieron a llenar ese silencio soterrado (Levi, 2000, p.15). La intención de Didi-Huberman es comprensible. Cada imagen era un foco de luz sobre un genocidio silencioso y silenciado entre las alambradas de los campos de concentración. Era una posibilidad de plantar cara al negacionismo y sobre todo de trabajar en favor de la memoria, a costa de convertir la imagen en una especie de reliquia sagrada. No todos los estudiosos consideran que el estudio de la imagen del holocausto debe seguir estancado en la polémica sobre la posibilidad de representación o no. Algunos como Kaplan (Kaplan, 2007) entienden la polémica ya agotada y no sólo reconocen a estas imágenes su representatividad, sino también su artisticidad.

La mayor parte de las imágenes fueron captadas por los agentes del exterminio y tampoco escapan a la distorsión. Esta fotografía, realizada a instancias de la máquina de guerra y destrucción nazi, respondía a intereses varios. Podríamos establecer tres grupos diferentes (Keilbach y Wächter, 2009, pp. 63-64). El tipo más sesgado de todos lo constituye sin duda lo que podríamos llamar foto-engaño o foto-máscara, cuya misión era ocultar a los ojos del mundo la verdad escondida tras los muros de sus pretendidos campos de reeducación. Terezin no fue el único gran falso decorado para ilustrar periódicos que contaran al mundo los logros de la racionalidad y modernidad germanas, en su empeño de mejorar las condiciones de vida de aquellas pobres gentes. Son imágenes preparadas, casi hollywoodianas, que sirven a los intereses propagandísticos internacionales del asesino. Hubo también, por supuesto, una fotografía destinada al uso interno de la administración y dedicada a reflejar la eficiencia del sistema y el modo en que se cumplían las distintas tareas programadas. Se trata sin duda del grupo de imágenes que mejor documentan la cotidianeidad de esta industria de la muerte. Y, finalmente, no puede faltar la imagen-souvenir tomada por el soldado represor que obliga a la víctima a un posado inmoral por la vejación que suponía el escarnio. Constituye la captación de la realidad más viciada de todas por el horror explícito reflejado en la impotencia de la víctima obligada al juego y la impostura, toda vez que su dignidad ya había quedado destruida. Las imágenes de las ejecuciones estaban totalmente prohibidas, pero las leyes no pudieron impedir la captura de estos momentos (Keilbach y Wächter, 2009, p. 65).

Todos estos tipos sufren además por igual una última distorsión derivada de la excesiva exposición, divulgación y reconocimiento de la imagen. El hábito a un símbolo acaba por hacerlo invisible y trivializarlo. Su asunción implica su desaparición. Hoy, ante el símbolo del cigarro bajo un aspa, nadie se detiene a pensar en lo que implica el hecho de fumar y sus consecuencias, asumimos que ese espacio es un espacio libre de humos y continuamos sin mayor problema, especialmente si no somos fumadores. De idéntica manera, la imagen del holocausto puede convertirse en algo inadvertido, no sugiere más allá de algo que sucedió y con lo que nuestro vínculo es nulo o extraordinariamente débil. La inadvertencia es mayor cuando el hábito de exposición a la imagen acaba sustituyendo su valor documental por un valor estético inherente a la fotografía como práctica también artística. La suplantación de un contenido por otro sustrae la imagen definitivamente y la adscribe a otra esfera atemporal, gobernada por el sentimiento y donde huelga la razón requerida por lo documental. 
La imagen adquiere un valor educativo a partir de los años 60, cuando deja de ser considerada sólo una prueba eficiente de todo lo acaecido en Europa.

\section{Re-aprendiendo a ver y a mirar}

La progresiva e inminente desaparición de los supervivientes obliga a replantearse la revisión del valor representativo de las imágenes de los campos (Farmer, 2010, p. 15). Los testimonios orales que habían mantenido viva la memoria resultaban cada vez más lejanos con la desaparición física de los narradores. Los monumentos y las fotografías recopiladas y expuestas con asiduidad comenzaban a ser, también a su vez, simples decorados urbanos o motivos de exhibiciones temporales. El miedo a representar lo que siempre se consideró irrepresentable había condenado la validez de cualquier testimonio gráfico y depositado el único reconocimiento y la veracidad solo en el relato de la víctima. Pero la imagen de lo terrible del momento había sido relegada a un segundo plano. Los encargados de poner la memoria en orden y custodiarla preferían siempre la palabra escrita a la imagen, mero ornato en los textos de los historiadores. Pero de pronto, asistidos por el boom de la historia del arte, los historiadores comienzan a comprender el alcance del análisis de lo que hasta entonces desdeñaron. La imagen, la fotográfica especialmente, tiene la virtud de ofrecer un aspecto de la realidad más o menos objetivo y propiciar en el espectador una reacción que nace de su sentimiento. Esta respuesta es totalmente humana y susceptible de ser analizada desde otros campos ya tradicionales en el estudio de la barbarie, como la psicología. Lo visual se convierte en objeto de estudio para la mayoría de campos científicos desde los que se había abordado el tema del holocausto, aunque tradicionalmente no hubiese interesado más que a fotógrafos y periodistas (Shneer, 2010, p. 28). La historia del arte jamás habría aspirado a un pedazo del pastel temático, que había sido repartido a priori entre historiadores y psicólogos preferentemente. Sin embargo, encuentra ahora, por su capacidad de aliar disciplinas diversas sobre el mismo objeto visual, que no sólo tiene algo que decir, sino que además puede ofrecer una doble solución al modo en que se ha de hacer perdurar la memoria: por un lado, resolviendo los problemas de interpretación y lectura integral de la imagen y, por otro, dando respuesta a los inconvenientes derivados del almacenamiento y musealización de los restos de ese bárbaro pasado. La historia del arte puede muy bien explorar la relación entre lo visual, la palabra hablada y el texto, unificando así objetos de estudio y métodos de análisis diferentes. Puede además comprender y esclarecer el papel de la imagen en la configuración de un ideario común sobre conceptos como la guerra o en la identificación de lo visual con una causa nacional o identitaria. Al fin y al cabo, la imagen artística es también la manifestación de un modo de ser peculiar frente a los otros. Lo icónico es un instrumento peligroso dependiendo de su uso. La fotografía documental soviética, por ejemplo, no presenta a los judíos agraviados y liberados como judíos, sino como ciudadanos soviéticos o seres humanos en general (Shneer, 2010, p.38), siguiendo unas férreas directrices políticas tendentes a la unificación de todos los pueblos y etnias de la joven comunidad soviética. El problema surge, pues, del uso indiscriminado de esas imágenes vergonzantes que mostraban sujetos cuyos números tatuados habían sido de nuevo sustituidos por nombres y apellidos, que en muchos casos habían continuado con su vida tras el horror y habían guardado el trauma sin querer expresarlo para no lastimar a sus descendientes. La decisión sobre la legitimidad de uso de esos documentos históricos y visuales les correspondía a ellos por entero, máxime cuando un mismo documento podía ser objeto de interesadas lecturas sesgadas por la ideología o el antojo del usuario (Farmer, 2010, p. 118) o cuando en aras de una sensibilización masiva con el tema, comienzan a utilizarse los medios de masas o la cinematografía.

Surge una cuestión más acerca de la validez de la fotografía del trauma y es que, como señala Sontag:

Hay algo depredador en la acción de hacer una foto. Fotografiar personas es violarlas, pues se las ve como jamás se ven a sí mismas, se las conoce como nunca pueden conocerse; transforma a las personas en objetos que pueden ser poseídos simbólicamente (2008, p. 24). 
La obra de arte es la captación de una mirada sobre el mundo (Wajcman, 2005, p. 20) que encierra dos enigmas: lo que el artista ve y lo que quiere representar. En realidad siempre nos conduce a algo más allá de ella misma, ya que nos proyecta a un tiempo diferente y futuro. Uno de los inconvenientes que se plantea con la representación gráfica del holocausto surge precisamente a partir de su especificidad. A lo largo de la historia del arte, la pintura histórica ha asignado una imagen representativa a los hechos acaecidos sin mayor dificultad. Desde la distancia cronológica a menudo se han construido imágenes que han ayudado a visualizar un pasado desde la óptica de estilo y del autor. En cualquier caso, estas representaciones se han convertido en referente a unos hechos que la historia explicaba por su parte desde los textos como fruto de la investigación. El problema del holocausto estriba en su innegable historicidad y su inmediatez a una serie de sistemas de representación gráficos que, como la fotografía, constituyen los mejores aliados de la verdad. En otras palabras, no cabe representación cuando la imagen se explica por sí sola y corresponde a la estricta veracidad. No cabe la mente de un artista ideando y componiendo una imagen explicativa que ya ha sido proporcionada por la fotografía. Esto implica que la práctica artística desarrollada después del genocidio sobre el tema del holocausto por artistas supervivientes, descendientes o sensibilizados con él, de algún modo se ve liberada del rigor histórico y puede concederse la libertad de hacer que prime la expresión del sentimiento sobre la del dato fidedigno. No es importante desde este momento que el arte sea figurativo o abstracto. Si el primero parecería estar más próximo al dato, como el segundo lo estaría al sentimiento, lo cierto es que indistintamente ambos estilos ayudan a la expresión de lo inexplicable.

Cuestión aparte, fundamental en la pintura de historia, pero no en este caso, es qué momento debe ser el representado y qué imagen por tanto debe convertirse en el referente de eso que genéricamente llamamos holocausto. La historia del arte recoge tantas respuestas como las existentes en la historia a la hora de enfrentarse al tema: el mundo judío inmerso en la locura generalizada de la época, la vida de angustia en los campos, la cámara de gas, el crematorio... El holocausto puede entenderse como un único objeto o como un todo compuesto de diferentes elementos (Lang, 1995, p. 89) y cualquiera de ellos es válido una vez que el arte se ve liberado de la necesidad de constatar y da rienda a la expresión. No caben problemas como los generados con el caso de la fotografía: el holocausto es inefable porque nadie sobrevivió a la cámara, no se puede contar lo que nadie contó. Pero la cámara y su inefabilidad, son un hecho y generan un sentimiento y su expresión es tan real y legítima como la de cualquier otra muestra artística. Esa es la razón de que la imagen plástica camine por otros derroteros a los exigidos a la fotográfica. Ambas con sus dosis de valor artístico y documental, ambas capaces de representar como referentes todo un hito histórico increíble por su singularidad, pero cada una de ellas con posibilidades de lectura e interpretación muy diferentes.

\section{Asunción de la realidad: imagen o relato}

El arte no es jamás la copia pasiva y fidedigna de la realidad, sino una realidad repensada por el artista y ofrecida a un público que, a su vez, deberá inferirla a partir de los trazos que este le brinda. Esto implica un choque inevitable entre la concepción previa del propio espectador y la elaborada por el artista. La obra es solo un pretexto para la adecuación de ambas y una oportunidad para reformular la realidad a la que asistimos, organizándola, estructurándola y asumiéndola a partir de los hitos más destacados. El papel del artista parece mucho más interesante que el de simple documentalista, pues ofrece un esquema previo que será sometido a debate. El artista es un instrumento de la sociedad en su avance y, ante la crisis, denuncia y proporciona posibles salidas. En época de bonanza, advierte de las posibilidades del cambio nefasto y propone caminos hacia un mayor avance. Ante el conflicto, el artista sufre porque se le urge una toma de partido y una apuesta clarificadora que ilumine un poco la sinrazón.

El problema del artista con los acontecimientos del exterminio es inasumible. Si era personaje principal y actuaba en este drama como víctima, a duras penas se le concedería la posibilidad de ofrecer plásticamente su visión ordenada del esperpento en que se veía inmerso. Si fue superviviente, su visión a posteriori solo puede actuar sobre la nada, pues nada había, salvo la propia reflexión sobre el dolor. 
Pero, en cualquier caso, se le priva definitivamente de la posibilidad de actuar como demiurgo salvador. Este es el gran problema del arte en relación al holocausto, que no puede representar lo que ya no existe, como coetáneamente no le fue permitido representar lo que sí existía. Peor aún es la relación con la plástica de aquellos descendientes que han vivido un mundo caótico, que ya no les correspondía, desde la presión del dolor soterrado y el choque de un pasado real contra un presente igualmente real, pero distante de la víctima, que para siempre queda estancada o marcada al menos por la barbarie.

La relación del artista con el genocidio judío no es siquiera la relación del artista con el tema de la guerra. No es un arte que analice e investigue sobre el conflicto, en todo caso debería haber sido un arte que, desde el intento de negación del conflicto por parte de los perpetradores, elucidase sobre su realidad y consecuencias. Los artistas que toman partido ante la guerra lo hacen por uno $\mathrm{u}$ otro bando en función de su posicionamiento ideológico (Llorente, 2010, p. 226) y utilizan libremente el estilo que más se adecúe a su voluntad expresiva. Pero ante el horror no caben posicionamientos enfrentados, el artista no puede tomar partido sino por lo humano, frente a lo que le es ajeno. A veces la postura del artista es incomprensible, pero plasma muy bien el modo que el arte tiene de asumir una realidad fuera de lo humano. Zoran Mušič, un no judío condenado por pertenecer a la resistencia de Trieste, realiza unos ciento ochenta bocetos de la vida en el campo, pero según sus propias palabras no lo hace como protesta o como un reportero con intención de documentar, sino como artista. Por eso dibujaba solo lo que le interesaba (Clair, 2007, p. 79). Y, sin embargo, aunque Mušič insiste (Clair, 2008) en que no persigue documentar, sino que todo es fruto de un deber quizás hacia sí mismo, como bastión de humanidad frente a lo despersonalizado, como artista consigue lo que a veces un documentalista no logra, precisamente por esa selección en la representación y la artisticidad implícita al dibujo:

El artista los captó desde un punto de vista elevado y sin dibujar ningún fondo o elementos de referencia espacial, de modo que se exponen a nuestra mirada sin posibilidad alguna de ocultarse, pues están solos. Tendidos en el suelo o amontonados con las bocas desencajadas muestran, ya sin posibilidad de pudor alguna, el sexo inerte (Llorente, 2010, p. 232).

Afirma J. Blutinger (2009, p. 269) que el gran escollo de la enseñanza sobre hechos como el holocausto es que generalmente tiende a verse y a utilizarse el lenguaje propio del perpetrador del crimen y que lo lógico sería hacerlo prestando idéntica atención al punto de vista de la víctima. Esto significa conferir a su testimonio el valor de documento histórico y recrear lo sucedido también desde su propia conciencia, en vez de tratarla tan solo como víctima paciente. Sin embargo, a diferencia de lo ocurrido con otras minorías no judías (Blutinger, 2009, pp. 270-273), como gitanos u homosexuales, surge un nuevo problema para la enseñanza adecuada de los hechos históricos a partir de este tipo de testimonios: su extraordinaria cantidad y variedad. Al margen, y siguiendo de nuevo a Blutinger (2009, pp. 274-276), hallamos otras dificultades que deben ser tenidas en cuenta en el uso del testimonio personal, oral o escrito, como documento para la enseñanza: El relato personal es el relato de un superviviente y el estudiante puede tener la sensación de que lo que es un hecho excepcional y fortuito fue la generalidad. Buena parte de los supervivientes pertenecían a una minoría de víctimas en los campos, integrantes de una extraña zona gris como la llamó Primo Levi, que a menudo sirve a los perpetradores para prolongar su vida a costa de su estabilidad moral y emocional. Esto lleva a ver la realidad desde la iustificatio non petita. La víctima, además, suele añadir a su narración imágenes adquiridas a posteriori, tomadas en préstamo de documentos visualizados o de otras narraciones individuales y esto distorsiona la propia realidad personal, aunque enriquezca la comprensión de lo sucedido y ofrezca a menudo una explicación a lo que en aquel momento era incomprensible para la víctima testigo. Los relatos escritos suelen contener licencias poéticas, frente a la inmediatez de la expresión oral, más desordenada, pero más espontánea y por tanto más veraz. No podemos olvidar que el sujeto narrador es un ser humano que ha sufrido y el padecimiento a veces lleva a la mente del individuo a presentar los hechos de formas muy distintas y encubiertas, acallando el dolor, obviando lo desagradable o construyendo una metáfora o alegoría que es mostrada como real. Lo personal y la persona interpretan la barbarie en términos humanos. Los relatos de los descendientes recogen las vivencias de familiares, pero la recreación es doble. 
Por más rigor y objetividad que se emplee en la transmisión del testimonio recibido de primera mano, las lagunas son inevitables e impiden la comprensión total de lo real (Tinberg, 2005, p.76).

\section{El compromiso del historiador del arte: arte y museos para la paz}

En el aire, constante, la pregunta sobre lo diferente que podría haber sido el relato si las imágenes a las que concedemos una cierta veracidad se hubiesen publicado durante el proceso de aniquilación sistemático, que sucedió, no obstante, oculto a los ojos del mundo. Quizá lleguemos a comprender el papel y poder de la imagen si pensamos en el efecto causado por la publicación de las instantáneas de tortura en Abu Ghraib (Hesford, 2006, p.31): los movimientos de repulsa, la opinión unánime fuera de Estados Unidos, la apropiación icónica de las mismas por parte de una población que se identificaba en esas víctimas. Esas imágenes de la polémica en cierto modo desencadenaron una oleada de paz. Sin duda, el relato habría sido otro de haber contado con algo similar en el transcurso de la guerra, porque la imagen de la guerra, aun siéndolo, no es la imagen de la ignominia. Estamos habituados y preparados para digerir la imagen del conflicto, es la imagen del horror gratuito lo que hace saltar nuestros resortes y esas imágenes no se vieron hasta el final de la contienda. Abu Ghraib ciertamente desencadenó una repulsa, no solo por la plasmación de la deshumanización y la tortura, pues lo más molesto era precisamente la puesta en escena, lo artístico en la imagen, por así decirlo. Lo más corrosivo era pensar que alguien tuviese la capacidad de preparar la escena para acentuar lo inhumano de la situación, la vejación dramatizada, y captarla entonces. No es nuevo, también existió este tipo de imágenes en los campos, lo novedoso es el alcance que estas más modernas tuvieron. ¿Habría sido otra la historia? El buenismo suscitado por su visión, la identificación con la víctima sin reservas, no significa sin embargo que se estén creando condiciones para la paz. Estamos hablando de sentimientos y la paz, más que sentimiento es razón. Por eso, sí que podemos hablar del arte generado por el holocausto, tras él, como de un arte para la paz, porque se trata de un sentimiento racionalizado, expresión con forma de un contenido, materialización a partir de un sentimiento repensado. El paso del tiempo convierte este material gráfico en museable y lo recubre de connotaciones que desvirtúan su significado. Carecemos de la preparación necesaria para reinvestirlo de su carácter documental y sustraerlo convenientemente al efecto artístico que lo amenaza. Este problema se da en mayor o menor grado en todos los museos y colecciones relacionadas: desde los dibujos infantiles de Terezin a la crudeza de Auschwitz o cualquier otro centro dedicado al Holocausto en cualquier parte del mundo. De algún modo, la musealización de los propios campos de exterminio convertidos en continentes viene a relevar a la imagen de su misión de testimonio de lo real.

Hay obras cuya naturaleza estética es innegable. Nacidas como expresión artística entre las manos de los supervivientes, no pueden sin embargo renunciar a su carácter documental para acentuar su valor estético. El tema consiste básicamente en averiguar cómo se estetiza el documento y cómo se documentaliza lo estético. Debemos establecer las diferentes funciones y valores que se aúnan en la pieza (documental, artístico, emocional...) e indagar el modo de reforzarlos y presentarlos al espectador de una manera lógica y ordenada, sin posible confusión. Acaso sea la formación artística actual la que prepara públicos para percibir determinados soportes como la fotografía en blanco y negro con una mirada estética descontextualizadora o quizás el modo contemporáneo de consumo artístico, que nos mueve a mirar las imágenes del horror como si se tratase de una producción cinematográfica. No obstante, muchas de estas piezas carecen de la chispa que mantiene vivo el juego del arte y esta ha debido ser depositada a través de subterfugios como su museificación. La exposición melodramática, que busca la fácil identificación emocional con el dolor de la víctima, pero sin promover la comprensión racional de lo sucedido ni un compromiso de acción moral (Goldberg, 2009, p. 234), es sin duda el mayor error a la hora de presentar o representar los hechos acaecidos. Con frecuencia, los visitantes a este tipo de exposiciones pueden justificar su sentimiento hacia el dolor judío, son incluso capaces de dar nombre a la víctima cuyo testimonio han oído en la proyección visual, pero muestran cierta dificultad a la hora de identificar una causa histórica, acudiendo simplemente a la maldad humana, a la crueldad nazi, a la debilidad o incapacidad de respuesta judía... La lágrima fácil enciende la llama del 
sentimiento al tiempo que apaga la luz de la razón. Por esta razón es tan importante que se cuide tanto el continente como lo espacial y la presentación racional y aséptica del contenido. La tarea del historiador del arte es investigar, preparar y formar al público para recibir la información de la Shoá al margen de su posible valor estético. Es también establecer la forma de explicar la diferencia entre estos niveles desde la educación más temprana. No basta con presentar las condiciones históricas y los modos de vida judíos en la Europa del momento, lo esencial es demostrar la intensa subversión de ese orden. Si en ocasiones ese orden ya ofrecía una vida bajo mínimos, la decisión nazi del exterminio total, la agrava y la trastorna de un modo perverso. Los valores morales que permitieron esa degradación de lo humano deben estar también presentes en la exposición, deben identificarse y presentarse, para poder comprender que el mal que todos comprenden fue consecuencia de un quiebro en la sociedad europea de entreguerras. En tanto que historiador, debe ser también profesionalmente capaz de incardinar estos elementos en la exposición. Curiosamente, el cambio en la concepción del mundo se expresa tanto en la imagen, más en la pictórica que en la fotográfica, como en la palabra, ya sea escrita o hablada. "The language is a more reliable witness and source of truth than other, material artifacts" (Rosenfeld, 2002, pp. 230-231). Introducir el vocabulario habitual en la información de la exposición ayudaría también a la adquisición de conceptos y a la aproximación de la estructura de visión de la realidad y pensamiento. Los relatos permiten aflorar la identidad del narrador a medida que comparte su testimonio con un público que interactúa. A menudo el vocabulario empleado supone también un cierto distanciamiento por parte del oyente, que no conoce el verdadero sentido de las palabras o se ve forzado al uso de una traducción. La propia naturaleza oral del testimonio implica así, en cierto modo, un enorme alejamiento. Las exposiciones documentales pueden convertirse en espacios culturales idóneos para presentar las cuestiones éticas y morales planteadas por la repetición del trauma y la violación de los derechos humanos.

\section{A modo de conclusión}

El holocausto supuso una brecha en nuestra cultura e historia que obligó a la intelectualidad de Posguerra a redefinir los valores éticos y estéticos. La creación artística y los modos de uso del arte experimentaron una serie de cambios que caracterizan el nuevo orden mental y moral nacido de tan dramática tensión. La imagen relacionada con el holocausto nacida de los campos de concentración o salida de los objetivos fotográficos de los reporteros desempeña una función preferentemente testimonial. Sin embargo, esta constatación de la realidad acaecida no consigue quedar exenta de una mirada puramente estética. La alianza entre la dura belleza de estas imágenes y su valor testimonial configura un ejercicio crítico de denuncia de primer orden.

La consideración de estas imágenes como productos de naturaleza doble, estética y documental, ha acompañado al proceso de conversión del holocausto en una seña de identidad judía, pese a que no se trata de un acontecimiento específicamente judío. Resulta por ello esencial salvaguardar el auténtico valor y significado de cada imagen, pues su conversión en símbolo lleva aparejada una cierta dosis de descontextualización y una pérdida relativa de su veracidad. La fotografía, a diferencia de otro tipo de imágenes plásticas, se caracteriza por su capacidad de precisión, comunica realidad y no se abre a la interpretación expresiva. No obstante, este acto de comunicación necesita de un conocimiento preciso de los hechos históricos también por parte del espectador, pues de carecer de este, la fotografía se entrega a la posibilidad de interpretación estética, simbólica o expresiva. De este modo, correría el riesgo de perder su validez de testimonio de lo real. Lo cierto es que, como documento, hemos de considerar que la fotografía también puede distorsionar la realidad de lo sucedido. No podemos olvidar que tras el visor hay siempre un ser humano que decide con su enfoque sobre el objeto capturado poner un acento y sugerir interpretaciones de aspectos que de por sí son mudos. Es esta la razón de que el uso de esta imagen necesitase del apoyo del testimonio de la víctima como medida correctora de posibles desvíos de la imaginación o simplemente del desconocimiento. La fotografía requiere de la palabra escrita o registrada en otros soportes para conseguir que pierda esta tendencia a la fantasía. 
El estudio del conflicto y de la dinámica bélica proporcionó una información abundante de variada naturaleza. Esto relegó la imagen del holocausto a un segundo plano, al no considerarse ya testimonio esencial por la avalancha de datos y documentos escritos de todo tipo. Los años sesenta imprimieron un giro al papel al que esta muestra plástica del pasado se había ido amoldando y consiguieron dotarla de una función mucho más rica al adscribirla al ámbito de la educación. No era solo una educación para la paz, en el deseo de que jamás volviera a repetirse el dominio de la barbarie sobre la razón, era también el pretexto adecuado para la construcción de una sociedad fundamentada en los nuevos valores deseables y garantes de un orden legítimo y profundamente humano. De este modo, la imagen del holocausto ha venido a constituir un instrumento hábil y muy útil para la educación en valores de las jóvenes generaciones que nada recuerdan sobre la guerra y el horror, pero que se aproximan a conocerlo con ojos inocentes y nuevos. El historiador del arte, conocedor de los arcanos de la imagen y su función, es sin duda uno de los profesionales que deben adquirir el compromiso con la transmisión idónea del pasado y de esos valores.

\section{Referencias}

Barnouw, D. (1996). Germany 1945: Views of War and Violence. Indiana Up.

Blutinger, J. (2009). Bearing Witness: Teaching the Holocaust from a Victim-Centered Perspective. The History Teacher, 42 (3), 269-279. https://doi.org/10.1163/2468-1733_shafr_sim130110030

Clair, J. (2007). La barbarie ordinaria. Music en Dachau. Antonio Machado Libros.

Clair, J. (2008). Zoran Mušič: De Dachau a Venecia. Fundació Caixa Catalunya.

Didi-Huberman, G. (2001). Images malgré tout. En C. Cheroux (Ed.), Memoire des Camps: Photographies des camps de concentration et d'extermination nazi (1933-1999) (pp. 219-242). Marval.

Feyertag, K. (2008). The Art of Vision and the Ethics of the Gaze. On the Debate on Georges Didi-Huberman's Book Images In Spite of All. EIPCP, 4. https://bit.ly/2zGkji1

Farmer, S. (2010). Going Visual: Holocaust Representation and Historical Method. The American Historical Review, 115 (1), 115-122. https://doi.org/10.1086/ahr.115.1.115

Friedman, Ph. (1976). Problems of Research on the European Jewish Catastrophe. En Y. Gutman y L. Rothkirchen (Eds). The Catastrophe of European Jewry: Antecedents. History.Reflections (pp. 633-650). Yad Vashem.

Godfrey, M. (2007). Abstraction and the Holocaust. Yale University Press.

Goldberg, A. (2009). The Victim's Voice and Melodramatic Aesthetics in History. History and Theory, 48 (3), 220-237. https://doi.org/10.1111/j.1468-2303.2009.00505.x

Gutman, Y. (2002). Reflection on Jewish Resistance under the Nazi German Occupation. Studies in Contemporary Jewry, 18, 109-125.

Hesford, W. (2006). Staging Terror. TDR (1988-), 50 (3), 29-41. https://doi.org/10.1162/dram.2006.50.3.29

Kaplan, B. (2007). Unwanted Beauty: Aesthetic Pleasure in Holocaust Representation. University of Illinois Press.

Keilbach, J. y Wächter, K. (2009). Photographs, Symbolic Images, and the Holocaust: On the (Im)Possibility of Depicting Historical Truth. History and Theory, 48 (2), 54-76. https://doi.org/10.1111/j.14682303.2009.00498.x 
Lang, B. (1995). Is It Possible to Misrepresent the Holocaust? History and Theory, 34 (1), 84-89. https:// doi.org/10.2307/2505585

Lang, B. (2005). Post-Holocaust: Interpretation, Misinterpretation, and the Claims of History. Indiana University Press.

Lanzman, C. (1994, 3 de marzo). A propos de La Liste de Schindler, dernier film de Steven Spielberg. Holocauste, la représentation impossible. Le Monde. https://bit.ly/2zTjgez

Levi, P. (2000). Los hundidos y los salvados. Muchnik Ed.

Llorente, Á. (2010). Arte en tiempos de guerra. En XIV Jornadas Internacionales de Historia del Arte. Editorial CSIC. Consejo Superior de Investigaciones Científicas.

Macdonald, D. (2007). First Nations, Residential Schools, and the Americanization of the Holocaust: Rewriting Indigenous History in the United States and Canada. Canadian Journal of Political Science / Revue Canadienne De Science Politique, 40 (4), 995-1015. https://doi.org/10.1017/ S0008423907071107

Novick, P. (1999). The Holocaust in American Life. Houghton and Mifflin.

Rosenfeld, O. (2002). In the Beginning Was the Ghetto. Northwestern University Press.

Shneer, D. (2010). Picturing Grief: Soviet Holocaust Photography at the Intersection of History and Memory. The American Historical Review, 115 (1), 28-52. https://doi.org/10.1086/ahr.115.1.28

Sontag, S. (2004). Regarding the Pain of Others. Picador.

Sontag, S. (2008). Sobre la fotografía. Debolsillo.

Tinberg, H. (2005). Taking (and Teaching) the Shoah Personally. College English, 68 (1), 72-89. https:// doi.org/10.2307/30044665

Wajcman, G. (2005). Arte y psicoanálisis: el vacío y la representación. Editorial Brujas.

Wajcman, G. (2001). De la croyance photographique. Les Temps Modernes. Gallimard, 613.

Wolkstein, O. y Mishani, D. (2006, 5 de septiembre). The World Is a Disaster Area. Ha'aretz. https://bit. ly/36RViwm 